\title{
Prevalence and Characteristics of Streptococcus canis Strains Isolated from Dogs and Cats
}

\author{
P. LYSKOVÁ ${ }^{1}$, M. VYDRŽALOVÁ ${ }^{1}$, D. KRÁLOVCOVÁ ${ }^{1}$, J. MAZUROVÁ $^{1}$ \\ ${ }^{1}$ Department of Biology and Biochemistry, Faculty of Chemical Technology, University of Pardubice, \\ Pardubice, Czech Republic \\ Received February 12, 2007 \\ Accepted October 2, 2007
}

\begin{abstract}
Lysková P., M. Vydržalová, D. Královcová, J. Mazurová: Prevalence and Characteristics of Streptococcus canis Strains Isolated from Dogs and Cats. Acta Vet. Brno 2007, 76: 619-625.

To determine the prevalence of Streptococcus canis in dogs and cats, a total of 926 swabs were examined bacteriologically in the period from 2003 to 2005. Eighty-six isolates obtained from various anatomical locations were further characterized for their phenotypic properties. The most frequently isolated biotype produced phosphatase, leucine amidopeptidase, arginine dihydrolase, alpha-D- and beta-D-galactosidase and fermented lactose and ribose. Additional identification by species-specific amplification of the $16 \mathrm{~S}-23 \mathrm{~S}$ rRNA intergenic spacer region was consistent with $S$. canis. All isolates were susceptible to penicillin $\mathrm{G}$ and ampicillin. The least effective antimicrobial agent was found to be tetracycline (only $33.8 \%$ of susceptible strains).
\end{abstract}

Prevalence, S. canis, biochemical properties, 16S-23S rRNA intergenic spacer region

Streptococcus (S.) canis belongs to Lancefield serogroup G, which forms heterogeneous group of beta-hemolytic streptococci. Presently, three taxonomic types of this serological group can be distinguished, as follows: minute colony formers from humans ( $S$. anginosus group), and large colony formers from humans $(S$. dysgalactiae ssp. equisimilis) and animals (S. canis).

The species $S$. canis was officially described by Devriese et al. (1986) and is considered to be part of healthy microbiota of skin and mucosa of animals, especially dogs and cats, and the udders of cows, although it may be responsible for opportunistic infections. In dogs, S. canis is isolated from a variety of diseases including skin infections, infections of urogenital and respiratory tracts, otitis externa, septicaemia, necrotizing fasciitis and streptococcal toxic shock syndrome (Bornand 1992; Miller et al. 1996; DeWinter et al. 1999). S. canis also causes various infections in cats, including arthritis, wound infections, septicaemia and streptococcal toxic shock syndrome, and it can cause mastitis in cows (Iglauer et al. 1991; Hassan et al. 2005). Very few human infections with $S$. canis have been documented; however, human infections with this species may be underestimated because many clinical isolates are reported to only as "group G Streptococcus". Syndromes that have been associated specifically with $S$. canis include septicaemia, meningitis and peritonitis (Bert and Lambert-Zechovsky 1997; Takeda et al. 2001; Whatmore et al. 2001).

In the present study, we isolated $S$. canis from specimens collected from healthy household pets and from pets with various opportunistic infections. These strains were characterized for their phenotypic properties and examined for their susceptibility to selected antimicrobial agents. Identification of all $S$. canis strains was confirmed by species-specific polymerase chain reaction (PCR).

\section{Materials and Methods}

Bacterial strains

Eighty six $S$. canis strains included in this study had been recovered from patients at the Veterinary Clinic of Pardubice during the period from 2003 to 2005. Samples were taken from 124 dogs and 21 cats with proceeding

Address for correspondence:

Mgr. Petra Lysková

Department of Biology and Biochemistry

Faculty of Chemical Technology

University of Pardubice

Phone: + 420466037704

Štrossova 239, 53003 Pardubice, Czech Republic

E-mail: petra.lyskova@upce.cz

http://www.vfu.cz/acta-vet/actavet.htm 
infection. In addition, 199 dogs and 50 cats without clinical signs of infection were included in the study. S. canis ATCC 43496, kindly provided by Dr. J. Motlová (National Institute of Public Health, Prague, CZ) was used as a positive control for PCR reaction. Staphylococcus aureus ATCC 25923 and S. agalactiae CCM 6187, from the Department of Microbiology culture collection, were used to perform CAMP reaction.

Isolation

Samples were cultured by using blood agar base supplemented with 5\% sheep blood, Edward's modified medium supplemented with 7\% sheep blood (both Oxoid, UK) and Slanetz and Bartley medium (HiMedia Laboratories, India). The plates were incubated at $37^{\circ} \mathrm{C}$ for $24 \mathrm{~h}$ in normal atmosphere. Colonies resembling streptococci and surrounded by a zone of beta-haemolysis were selected for further investigation. Subsequently, all streptococcal strains were cultured by using Todd-Hewitt broth and blood agar base (both Oxoid, UK) supplemented with 5\% sheep blood. The plates and tubes were incubated at $37^{\circ} \mathrm{C}$ for $24 \mathrm{~h}$ in normal atmosphere. After the incubation period the strains were subjected to species identification and also evaluated for antimicrobial susceptibility.

Phenotypic identification

The biotype of each $S$. canis strain was determined by the STREPTOtest 16 identification system using the Identification program TNW lite 6.0 (PLIVA-Lachema a.s., CZ). Lancefield typing was performed by latex agglutination using ITEST STREPTO GROUP (ITEST plus s.r.o., CZ). For the CAMP test, each isolate was streaked on 5\% sheep blood agar plates at right angles to beta-haemolysin producing strain of Staphylococcus aureus and incubated overnight at $37^{\circ} \mathrm{C}$. S. agalactiae was included as a positive control. After incubation, plates were examined for synergistic haemolysis between the two organisms (Lammler et al. 1987).

Antimicrobial susceptibility testing

Following antimicrobial agents were used for disk diffusion testing: penicillin G, ampicillin, chloramphenicol, vancomycin, tetracycline, erythromycin and clindamycin (Oxoid, UK). In preparation for testing, the strains were grown overnight on $5 \%$ sheep blood agar plates at $37^{\circ} \mathrm{C}$. A bacterial suspension equal to a McFarland standard of 0.5 prepared in $0.85 \%$ saline was used to inoculate plates containing Mueller-Hinton agar (Oxoid, UK) supplemented with $5 \%$ sheep blood. The inhibitory zone diameters obtained around the antibiotic disks were measured after incubation for $24 \mathrm{~h}$ at $37^{\circ} \mathrm{C}$. Susceptibility, intermediate susceptibility and resistance to antibiotics were interpreted according to the recommendations of National Committee for Clinical Laboratory Standards (2001).

Species-specific PCR

PCR was performed with primer c-I 5'-TAAACCGAAAACGCTGTAAGTATTA-3' and primer c-II 5'ACCATTAGTTAGTGGGTTCCCCC-3' as described previously by Hassan et al. (2003). The species-specific primers were targeted to 16S-23S rRNA intergenic spacer region and forming the amplicon with a size of 215 bp. The PCR reaction mixture $(24 \mu \mathrm{l})$ contained $0.18 \mu \mathrm{l}$ primer c-I $\left(100 \mathrm{pmol} \cdot \mu \mathrm{l}^{-1}\right)$ and $0.18 \mu \mathrm{l}$ primer $\mathrm{c}$-II $(100$ pmol· $\left.\mu^{-1}\right), 2 \mu$ dNTP $(2.5 \mathrm{mM}$ each, TAKARA BIO INC., Japan), $2.5 \mu 110 \times$ PCR buffer (TAKARA BIO INC.), $1.5 \mu \mathrm{MgCl}_{2}\left(25 \mathrm{mM}\right.$, TAKARA BIO INC.), $0.13 \mu \mathrm{l} \mathrm{Taq} \mathrm{DNA} \mathrm{polymerase} \mathrm{(5} \mathrm{U \cdot \mu l-1}{ }^{-1}$ TAKARA BIO INC.) and $17.52 \mu \mathrm{l}$ distilled water. Finally one colony of tested strain was added to each reaction tube. The PCR assay was performed using Robocycler Gradient 96 (Stratagene, USA) as follows: initial denaturation at $94{ }^{\circ} \mathrm{C}$ for $4 \mathrm{~min}$, 30 cycles of denaturation at $94{ }^{\circ} \mathrm{C}$ for $10 \mathrm{~s}$, annealing at $61{ }^{\circ} \mathrm{C}$ for $30 \mathrm{~s}$ and extension at $72{ }^{\circ} \mathrm{C}$ for $10 \mathrm{~s}$. Finally, a 10 -min extension period at $72{ }^{\circ} \mathrm{C}$ was carried out. Positive and negative controls were included in each run of amplification. The presence of a specific PCR product was controlled by electrophoresis of $10 \mu l$ of the reaction product in a $1.5 \%$ agarose gel (SERVA Electrophoresis GmbH, Germany). The molecular weight of amplification product was determined using 100-bp DNA ladder (FERMENTAS INTERNATIONAL INC., Canada).

\section{Results}

Of the total of 394 animals included in this study, 58 (18\%) dogs and $9(12.7 \%)$ cats were positive for $S$. canis. The prevalence of $S$. canis samples taken from various anatomical locations of healthy animals and animals with proceeding infection (Tables 1 and 2) revealed a preponderance of recoveries from the rectum. The occurrence of $S$. canis in animals with proceeding infection is summarized in Fig. 1. Of 145 samples taken from local infections, $31(21.4 \%)$ were positive for $S$. canis. This microorganism was most frequently isolated from animals with otitis externa. On the other hand, we did not find $S$. canis in specimens taken from animals with rhinitis.

All 86 beta-haemolytic streptococcal isolates belonged to the Lancefield serogroup $\mathrm{G}$ and were classified as $S$. canis. According to the biochemical test results (listed in Table 3 ), the $86 S$. canis isolates had 22 biotypes. The most common biotype (31 of 86 strains or $36 \%$ ) produced phosphatase, leucine amidopeptidase, arginine dihydrolase, alpha-D- and beta-Dgalactosidase and fermented lactose and ribose. All isolates produced arginine dihydrolase and failed to produce pyrrolidonylarylamidase. All isolates also failed to ferment sorbitol, 
Table 1. Frequency of Streptococcus canis isolated from various anatomical sites of healthy dogs and cats

\begin{tabular}{|c|c|c|c|c|c|c|}
\hline \multirow{3}{*}{$\begin{array}{c}\text { Anatomical sites } \\
\text { External ear canal }\end{array}$} & \multicolumn{3}{|c|}{ Dogs } & \multicolumn{3}{|c|}{ Cats } \\
\hline & \multirow{2}{*}{$\begin{array}{l}\text { Total of specimens } \\
(\mathrm{n}=539)\end{array}$} & \multicolumn{2}{|c|}{$\begin{array}{l}\text { Number }(\%) \text { of } \\
\text { S. canis strains } \\
\quad(\mathrm{n}=35)\end{array}$} & \multirow{2}{*}{$\begin{array}{c}\text { Total of specimens } \\
(\mathrm{n}=169)\end{array}$} & \multicolumn{2}{|c|}{$\begin{array}{l}\text { Number }(\%) \text { of } \\
\text { S. canis strains } \\
\quad(\mathrm{n}=10)\end{array}$} \\
\hline & & 4 & $(2.2)$ & & 1 & (1.9) \\
\hline Nasal mucosa & 10 & 0 & $(0)$ & 1 & 0 & $(0)$ \\
\hline Pharynx and oral cavity & 84 & 7 & (8.3) & 38 & 4 & $(10.5)$ \\
\hline Conjunctivae & 12 & 0 & $(0)$ & 16 & 1 & $(6.3)$ \\
\hline Skin & 44 & 3 & $(6.8)$ & 25 & 0 & $(0)$ \\
\hline Praeputium & 48 & 6 & $(12.5)$ & 0 & 0 & $(0)$ \\
\hline Vaginal mucosa & 30 & 2 & $(6.7)$ & 3 & 0 & $(0)$ \\
\hline Rectum & 127 & 13 & $(10.2)$ & 34 & 4 & $(11.8)$ \\
\hline
\end{tabular}

Table 2. Frequency of Streptococcus canis isolated from various anatomical sites of dogs and cats with proceeding infection

\begin{tabular}{|c|c|c|c|c|c|c|}
\hline \multirow{3}{*}{$\begin{array}{r}\text { Anatomical sites } \\
\text { External ear canal }\end{array}$} & \multicolumn{3}{|c|}{ Dogs } & \multicolumn{3}{|c|}{ Cats } \\
\hline & \multirow{2}{*}{$\begin{array}{l}\begin{array}{c}\text { Total of specimens } \\
(\mathrm{n}=176)\end{array} \\
101\end{array}$} & \multicolumn{2}{|c|}{$\begin{array}{l}\text { Number }(\%) \text { of } \\
\text { S. canis strains } \\
\quad(\mathrm{n}=39)\end{array}$} & \multirow{2}{*}{$\begin{array}{l}\begin{array}{l}\text { Total of specimens } \\
(\mathrm{n}=42)\end{array} \\
16\end{array}$} & \multicolumn{2}{|c|}{$\begin{array}{l}\text { Number }(\%) \text { of } \\
\text { S. canis strains } \\
\quad(\mathrm{n}=2)\end{array}$} \\
\hline & & 19 & $(18.8)$ & & 0 & $(0)$ \\
\hline Nasal mucosa & 1 & 1 & $(100)$ & 1 & 0 & $(0)$ \\
\hline Pharynx and oral cavity & 18 & 3 & $(16.7)$ & 7 & 1 & $(14.3)$ \\
\hline Conjunctivae & 1 & 0 & $(0)$ & 1 & 0 & $(0)$ \\
\hline Skin & 21 & 3 & $(14.3)$ & 8 & 0 & $(0)$ \\
\hline Praeputium & 8 & 1 & $(12.5)$ & 1 & 0 & $(0)$ \\
\hline Vaginal mucosa & 6 & 3 & $(50.0)$ & 1 & 0 & $(0)$ \\
\hline Rectum & 20 & 9 & $(45.0)$ & 7 & 1 & $(14.3)$ \\
\hline
\end{tabular}

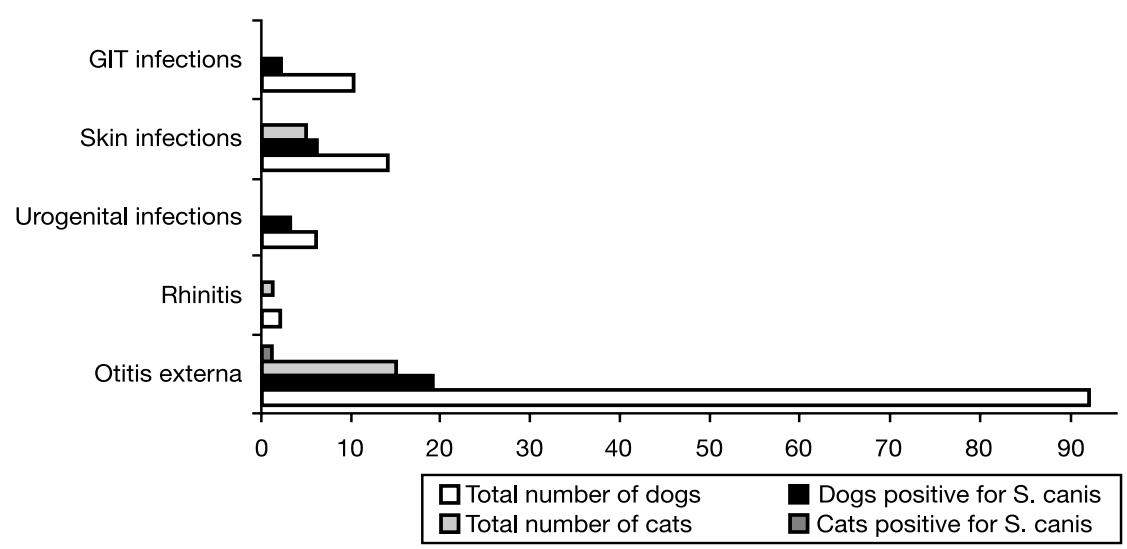

Figure 1. The occurrence of $S$. canis in dogs and cats with proceeding infection

inulin, raffinose and mellibiose. CAMP-like reaction was performed on sheep blood agar plates and could be observed for $58.1 \%$ (50 out of 86 ) of $S$. canis strains.

The results of antimicrobial susceptibility tests (Table 4) showed that all isolates were sensitive to penicillin $\mathrm{G}$ and ampicillin. The least effective antimicrobial agent was found 
Table 3. Biochemical properties of $S$. canis strains isolated from dogs and cats

\begin{tabular}{|l|c|c|}
\hline \multirow{2}{*}{ Test } & \multicolumn{2}{c|}{$\begin{array}{c}\text { Number (\%) of positive } \\
\text { S. canis strains (n = 86) }\end{array}$} \\
\hline Pyrrolidonyle arylamidase & 0 & $(0)$ \\
\hline Voges-Proskauer test & 2 & $(2.3)$ \\
\hline Hippurate & 1 & $(1.2)$ \\
\hline Phosphatase & 76 & $(88.4)$ \\
\hline Leucine amidopeptidase & 83 & $(96.5)$ \\
\hline beta-D-Glucuronidase & 10 & $(11.6)$ \\
\hline alpha-D-Galactosidase & 83 & $(96.5)$ \\
\hline Esculin & 14 & $(16.3)$ \\
\hline Arginine & 86 & $(100)$ \\
\hline Urease & 2 & $(2.3)$ \\
\hline Mannitol & 1 & $(1.2)$ \\
\hline Sorbitol & 0 & $(0)$ \\
\hline Trehalose & 13 & $(15.1)$ \\
\hline Lactose & 65 & $(75.6)$ \\
\hline Raffinose & 0 & $(0)$ \\
\hline Inulin & 0 & $(0)$ \\
\hline Mellibiose & 0 & $(0)$ \\
\hline Ribose & 67 & $(77.9)$ \\
\hline beta-D-Galactosidase & 80 & $(93.0)$ \\
\hline CAMP-like reaction & 50 & $(58.1)$ \\
\hline
\end{tabular}

to be tetracycline (only $33.8 \%$ of susceptible strains). The respective rates of resistance to vancomycin, chloramphenicol, erythromycin and clindamycin were $10.5 \%, 7 \%, 3.5 \%$ and $2.3 \%$, respectively.

Using species-specific oligonucleotide primers, all $86 \mathrm{~S}$. canis strains were detected yielding an amplicon with a size of 215 bp. S. dysgalactiae ssp. equisimilis, also belonging to the Lancefield serogroup $\mathrm{G}$, and all the other control strains of various species and serogroups were negative throughout.

\section{Discussion}

A total number of 86 of $S$. canis strains was isolated from 926 swabs obtained from 323 dogs and 71 cats in the period from 2003 to 2005 . The distribution of $S$. canis in samples from various anatomical locations shows the preponderance of recoveries from the rectum $(14.9 \%$ in dogs and $12.2 \%$ results are consistent with the findings of Moyaert et al. (2006) about the prevalence of S. canis in rectal swabs. On the other hand, our findings concerning the isolation rate of this bacterium from vagina appeared to be lower than other reports (Clemetson and Ward 1990; Gunzel-Apel et al. 1999; Siemieniuch et al. 2005). In these reports, the prevalence of $S$. canis in vaginal swabs was found to be $52 \%, 40 \%$ and $37.5 \%$, respectively. The differences in the occurrence of $S$. canis might be due to the differences in epidemiological conditions between countries. Concerning the distribution of S. canis in samples taken from sites with proceeding infections, it was cultivated from pathological processes localized in the genital tract, skin, and gastrointestinal tract and from otitis externa. It is not possible to estimate the contribution of $S$. canis to genital and gastrointestinal tract infections and skin infections due to the small number of samples in our study. As for specimens taken from animals with otitis externa, our results are consistent with observations of Bornand (1992) and Bensignor et al. (2000). However, considering the fact that $S$. canis was found almost only in mixed cultures, it most likely represents a secondary invading species. Within the

Table 4. Percentage of antibiotic susceptibility results for $S$. canis isolated from dogs and cats

\begin{tabular}{|l|c|c|c|c|}
\hline \multirow{2}{*}{ Antimicrobial agent } & \multirow{2}{*}{$\begin{array}{c}\text { Disk } \\
\text { content }\end{array}$} & \multicolumn{3}{|c|}{ S. canis (n=86 strains) } \\
\cline { 3 - 5 } & $10 \mathrm{U}$ & Susceptible & Intermediate & Resistant \\
\hline Penicillin G & $10 \mu \mathrm{g}$ & 100 & 0 & 0 \\
\hline Ampicillin & $30 \mu \mathrm{g}$ & 89.5 & 0 & 10.5 \\
\hline Vancomycin & $2 \mu \mathrm{g}$ & 90.7 & 7.0 & 2.3 \\
\hline Clindamycin & $30 \mu \mathrm{g}$ & 86.0 & 7.0 & 7.0 \\
\hline Chloramphenicol & $15 \mu \mathrm{g}$ & 87.2 & 9.3 & 3.5 \\
\hline Erythromycin & $30 \mu \mathrm{g}$ & 33.8 & 36.4 & 29.8 \\
\hline Tetracycline & & & 0 & 0 \\
\hline
\end{tabular}


group of animals with rhinitis we did not find any sample positive for $S$. canis. This is in contrast to the findings of Knotek et al. (2001), who found $7.5 \%$ of samples positive for S. canis.

All beta-haemolytic streptococci of the Lancefield serological group $\mathrm{G}$ isolated in this study belong to the species $S$. canis, as defined by Devriese et al. (1986). No significant differences in biochemical properties between $S$. canis strains isolated from healthy animals and from animals with proceeding infection were observed. There was one prevalent biotype among the isolated strains which produced phosphatase, leucine amidopeptidase, arginine dihydrolase, alpha-D- and beta-D-galactosidase and fermented lactose and ribose. Results from the biochemical tests that are typically variable (including pyrrolidonylarylamidase, alpha-D- and beta-D-galactosidase, beta-D-glucuronidase, and acidification of lactose and trehalose) were generally within the range of proportions reported for $S$. canis by other researchers (Clark et al. 1984; Devriese et al. 1986; Efstratiou et al. 1994; Vieira and Castro 1994; Soedarmanto and Lammler 1996). Only $16.3 \%$ of $S$. canis strains were positive for esculin hydrolysis, which is in contrast to the results of Devriese et al. (1986) and Vieira and Castro (1994), who found $100 \%$ and $90 \%$ of strains positive, respectively. On the other hand, Efstratiou et al. (1994) described only $40 \%$ of strains as esculin positive and all positive reactions were reported as delayed, which might be responsible for some of the discrepancy. According to Hassan et al. (2005) all S. canis isolates appeared to be esculin negative on primary culture; whereas, the isolates were uniformly positive after they were subcultured. This could be another potential source of variation.

Another phenotypic characteristic of $S$. canis investigated was the CAMP-like reaction which was positive for $58.1 \%$ of strains. Our results are lower than the observations of Lammler et al. (1987), Vieira and Castro (1994) and Facklam (2002), who reported CAMP-like reaction in $74.1 \%, 100 \%$ and $95 \%$ of strains, respectively. On the contrary, other studies have reported the absence of CAMP-like reactions (Clark et al. 1984; Devriese et al. 1986).

The antibiotic susceptibility patterns of $S$. canis isolates found in our study are generally in agreement with the findings of other authors (Wu et al. 1997; Kataja et al. 1998; Hassan et al. 2005; Moyaert et al. 2006). In addition, our rates of resistance to erythromycin and tetracycline are much lower than those reported by $\mathrm{Wu}$ et al. (1997), who found $38.2 \%$ of strains resistant to erythromycin and $73.5 \%$ of strains resistant to tetracycline. After tetracycline, the second least effective antimicrobial agent was found to be vancomycin. In this study, only $89.5 \%$ of $S$. canis strains were susceptible to vancomycin. Our results are lower than the observations of Wu et al. (1997), who reported 100\% of strains susceptible to vancomycin. On the other hand, Zaoutis et al. (1999) described tolerance to vancomycin in $66.7 \%$ of isolates. The significance of in vitro vancomycin resistance is uncertain, since our results may not reflect clinical efficacy. However, due to increasing resistance of bacterial isolates to antimicrobial agents, this study once more emphasizes the importance of susceptibility testing in order to establish correct therapeutic protocol.

For further characterization, the species-specific oligonucleotide primers were successfully used in PCR for the 16S-23S rDNA intergenic spacer region. The PCR methodology used in our study was based on the investigations of Hassan et al. (2003), who studied S. canis genes encoding $16 \mathrm{~S}$ rRNA and 16S-23S rDNA intergenic spacer region. The PCR method presented in this study allowed a rapid and reliable identification of $S$. canis and might help to improve the diagnosis of this bacterial species in animal and human infections.

In conclusion, the prevalence of $S$. canis among household pets was found to be $17 \%$ with the preponderance of recoveries from the rectum and genital tract. Although this microorganism is commonly isolated from the skin and urogenital tract of animals, it can still be responsible for various, mostly acute infections. Even if the biochemical characteristics are suitable to confirm the preliminary identification of $S$. canis isolates, 
additional molecular biological techniques may help with the unambiguous identification of $S$. canis isolates from clinical samples.

\section{Výskyt a vlastnosti kmenů Streptococcus canis izolovaných ze psů a koček}

Pro určení rozšíření druhu Streptococcus canis u psů a koček bylo bakteriologicky vyšetřeno celkem 926 vzorků odebraných v letech 2003 až 2005. U 86 izolovaných kmenů byly dále zjišt’ovány jejich fenotypové vlastnosti. Nejčastěji byl izolován biotyp, pro který byla charakteristická produkce fosfatázy, leucin-aminopeptidázy, arginin dihydrolázy, alfa-Da beta-D-galaktosidázy a tvorba kyselin z laktózy a ribózy. Další průkaz založený na amplifikaci druhově specifické oblasti 16S-23S rRNA potvrdil identifikaci S. canis. Všechny izolované kmeny byly citlivé na penicilin $\mathrm{G}$ a ampicilin. Jako nejméně účinný se jevil tetracyklin (jen 33,8 \% citlivých kmenů).

\section{Acknowledgement}

The study was supported by the Ministry of Education, Youth and Sports of the Czech Republic (Research Project No. 0021627502).

\section{References}

BENSIGNOR E, LEGEAY D, MEDAILLE C 2000: Prospective study on otitis externa in the adult dog in France. Prat Med Chir Anim 35: 405-414

BERT F, LAMBERT-ZECHOVSKY N 1997: Septicemia caused by Streptococcus canis in a human. J Clin Microbiol 35: 777-779

BORNAND V 1992: Bacteriology and mycology of otitis externa in dog. Schweiz Arch Tierheilkd 134: 341-348

CLARK RB, BERRAFATI JF, JANDA JM, BOTTONE EJ 1984: Biotyping and exoenzyme profiling as an aid in the differentiation of human from bovine group G streptococci. J Clin Microbiol 20: 706-710

CLEMETSON LL, WARD AC 1990: Bacterial flora of the vagina and uterus of healthy cats. J Am Vet Med Assoc 196: $902-6$

DEVRIESE LA, HOMMEZ J, KILPPER-BÄLZ R, SCHLEIFER KH 1986: Streptococcus canis sp. nov.: a species of group $\mathrm{G}$ streptococci from animals. Int J Syst Bacteriol 36: 422-425

DEWINTER LM, LOW DE, PRESCOTT JF 1999: Virulence of Streptococcus canis from canine streptococcal toxic shock syndrome and necrotizing fasciitis. Vet Microbiol 70: 95-110

EFSTRATIOU A, COLMAN G, HAHN G, TIMONEY JF, BOEUFGRAS JM, MONGET D 1994: Biochemical differences among human and animal streptococci of Lancefield group C or group G. J Med Microbiol 41: $145-148$

FACKLAM R 2002: What happened to the streptococci: overview of taxonomic and nomenclature changes. Clin Microbiol Rev 15: 613-630

GUNZEL-APEL AR, LUBKE A, ROHDE J 1999: A comparative study on the vaginal and uterine cytology and bacterial flora during the oestrous cycle and puerperium in beagle bitches. Tierarztl Prax 27: 112-119

HASSAN AA, KHAN IU, ABDULMAWJOOD A, LÄMMLER C 2003: Development of PCR assays for detection of Streptococcus canis. FEMS Microbiol Lett 219: 209-214

HASSAN AA, AKINEDEN O, USLEBER E 2005: Identification of Streptococcus canis isolated from milk of dairy cows with subclinical mastitis. J Clin Microbiol 43: 1234-1238

IGLAUER F, KUNSTYR I, MORSTEDT R, FAROUQ H, WULLENWEBER M, DAMSCH S 1991: Streptococcus canis arthritis in a cat breeding colony. J Exp Anim Sci 34: 59-65

KATAJA J, SEPPÄLÄ H, SKURNIK M, SARKKINEN H, HUOVINEN P 1998: Different erythromycin resistance mechanisms in group C and group G streptococci. Antimicrob Agents Chemother 42: 1493-1494

KNOTEK Z, FICHTEL T, KOHOUT P, BENÁK P 2001: Diseases of the Nasal Cavity in the Dog. Aetiology, Symptomatology, Diagnostics. Acta Vet Brno 70: 73-82

LÄMMLER C, GURTÜK K, BLOBEL H 1987. CAMP-like reactions of group G streptococci from dogs. Med Sci Res 15: 217-218

MILLER CW, PRESCOTT JF, MATHEWS KA, BETSCHEL SD, YAGER JA, GURU V, DEWINTER L, LOW DE 1996: Streptococcal toxic shock syndrome in dogs. J Am Vet Med Assoc 209: 1421-1426

MOYAERT H, DE GRAEF EM, HAESEBROUCK F, DECOSTERE A 2006: Acquired antimicrobial resistance in the intestinal microbiota of diverse cat population. Res Vet Sci 81: 1-7

NATIONAL COMMITTEE FOR CLINICAL LABORATORY STANDARDS 2001: Performance standards for antimicrobial susceptibility testing; Document M100-S10. Wayne Pa: National Committee for Clinical Laboratory Standards. 
SIEMIENIUCH M, FRONCZEK T, BLASZKOWSKA M, BIELAS W, DUBIEL A 2005: Bacterial flora of the genital-urinary tract in clinically healthy queens. Med Weter 61: 1305-1307

SOEDARMANTO I, LÄMMLER C. 1996. Comparative studies on streptococci of serological group G isolated from various origins. J Vet Med 43: 513-523

TAKEDA N, KIKUCHI K, ASANO R, HARADA T, TOTSUKA K, SUMIYOSHI T, UCHIYAMA T, HOSODA S 2001: Recurrent septicemia caused by Streptococcus canis after a dog bite. Scand J Infect Dis 33: 927-928

VIEIRA VV, CASTRO ACD 1994. Biochemical properties and whole-cell protein profiles of group G streptococci isolated from dogs. J Appl Bacteriol 77: 408-411

WHATMORE AM, ENGLER KH, GUDMUNDSDOTTIR G, EFSTRATIOU A 2001 Identification of isolates of Streptococcus canis infecting humans. J Clin Microbiol 39: 4196-4199

WU JJ, LIN KY, HSUEH PR, LIU JW, PAN HI, SHEU SM 1997: High incidence of erythromycin-resistant streptococci in Taiwan. Antimicrob Agents Chemother 41: 844-846

ZAOUTIS T, SCHNEIDER B, STEELE MOORE L, KLEIN JD 1999: Antibiotic Susceptibilities of Group C and Group G Streptococci Isolated from Patients with Invasive Infections. J Clin Microbiol 37: 3380-3383 
